\title{
DECYZJE O ŚRODOWISKOWYCH UWARUNKOWANIACH ORAZ ICH WYKONALNOŚĆ I WYKONANIE. ANALIZA PRAWNA
}

\section{DECISIONS ON THE ENVIRONMENTAL CONDITIONS AND THEIR EXECUTABILITY. LEGAL ANALYSIS}

\section{STRESZCZENIE}

Przedmiotem artykułu jest analiza jednej z cech decyzji administracyjnych - cechy wykonalności w odniesieniu do decyzji o środowiskowych uwarunkowaniach. W artykule przedstawiono analizę cechy wykonalności decyzji o środowiskowych uwarunkowaniach w oparciu o różne koncepcje wypracowane przez doktrynę. W artykule dokonano analizy cechy wykonalności pod kątem dopuszczalności przyznania

Doktor nauk prawnych, adiunkt na Wydziale Informatycznych Technik Zarządzania, Wyższa Szkoła Informatyki Stosowanej i Zarządzania w Warszawie, asystent sędziego w Trybunale Konstytucyjnym. 
ochrony tymczasowej w przypadku wniesienia skargi do sądu administracyjnego na decyzję o środowiskowych uwarunkowaniach.

\section{Słowa kluczowe}

Decyzja o środowiskowych uwarunkowaniach, wykonalność, wstrzymanie wykonania.

\section{ABSTRACT}

The subject of the article is an analysis of one of the characteristics of administrative decisions-characteristics of executability in relation to decisions on the environmental conditions. The article provides an analysis of the characteristics of executability in relation to decisions on the environmental conditions based on different concepts developed by doctrine. The article analyses also the executability required for granting temporary protection in case of the complaining to the administrative court against decision on environmental considerations.

\section{Keywords}

Decision on the environmental conditions, executability, suspension of execution.

Decyzja administracyjna jest, jako akt stosowania prawa, wydawana z zamiarem wywołania skutków prawnych. Do tych bezpośrednich zalicza się skutek procesowy wyrażający się w zakończeniu postępowania (w danej instancji lub też w ogóle) oraz skutek materialnoprawny mający postać rozstrzygnięcia o sytuacji prawnej adresata ${ }^{1}$.

Decyzja o środowiskowych uwarunkowaniach - co do zasady - ma na celu ustalenie konsekwencji wpływu realizacji przedsięwzięcia na środowisko. Podstawę prawną jej wydania,

1 K. Defecińska-Tomczak, M. Długońska, E. Frankiewicz, A. Korzeniowska, J. Wyporska, Wybrane zagadnienia z zakresu wykonalności decyzji administracyjnej, [w:] Procedura administracyjna wobec wyzwań wspótczesności, Łódź 2004, s. 74. 
obecnie obowiązującą, stanowi ustawa z dnia 3 października 2008 r. o udostępnianiu informacji o środowisku i jego ochronie, udziale społeczeństwa w ochronie środowiska oraz o ocenach oddziaływania na środowisko ${ }^{2}$. Przedmiotem artykułu jest analiza decyzji o środowiskowych uwarunkowaniach ze względu na cechę wykonalności, z uwzględnieniem tego, czy decyzja została wydana po przeprowadzeniu oceny oddziaływania na środowisko, czy tylko po tzw. screeningu ${ }^{3}$.

Chociaż w tytule artykułu pojawiają się wyrazy „wykonalność” i „wykonanie”, Janusz Borkowski zwraca uwagę, że nie zawsze użycie jednego z nich wynika z potrzeby zróżnicowania znaczenia prawnego, lecz zdarza się, że wiąże się ze zgrabną stylistyką formuły prawnej ${ }^{4}$. Na to, że prawodawca nie posługuje się w sposób ujednolicony terminami wyznaczającymi zakres tych pojęć, wskazuje Robert Sawuła, stwierdzając, że wykonanie jest następstwem wykonalności ${ }^{5}$.

Zdaniem Mikołaja Święckiego wykonalność jest konstrukcją teoretycznoprawną, utworzoną na podstawie analizy przepisów, które określają zarówno przesłanki dopuszczające wykonanie decyzji nieostatecznej, jak również nierozerwalnie

2 Dz.U. Nr 199, poz. 1227, ze zm.; dalej: ustawa ocenowa. Wprowadzenie obowiązku uzyskania odrębnej decyzji - decyzji o środowiskowych uwarunkowaniach - nastąpiło wraz z wejściem w życie ustawy z dnia 18 maja 2005 r. o zmianie ustawy - Prawo ochrony środowiska oraz niektórych innych ustaw, tj. z dniem 28 lipca 2005 r. Do czasu wprowadzenia zmiany, postępowanie środowiskowe stanowiło integralną część postępowań w przedmiocie wydania decyzji inwestycyjnych.

3 Ze względu na ograniczone ramy, jakie wiążą się z formą artykułu, w zakresie wyjaśnienia pojęć oceny oddziaływania na środowisko, screeningu, chciałabym odesłać do licznych prac naukowych, np. G. Dobrowolski, Decyzja o środowiskowych uwarunkowaniach, Toruń 2011, passim; M. Pchałek, M. Behnke, Postępowanie $w$ sprawie oceny oddziaływania na środowisko $w$ prawie polskim i UE, C.H. Beck 2009, passim.

4 Zob. System prawa administracyjnego, t. 9, Prawo procesowe administracyjne pod red. B. Adamiak, J. Borkowskiego, A. Skoczylasa, Warszawa 2010, s. 166.

5 Zob. R. Sawuła, Materialnoprawne aspekty wstrzymania wykonania decyzji administracyjnej, [w:] Wspótzależność dyscyplin badawczych $w$ sferze administracji publicznej, pod red. S. Wrzoska, M. Domagały, J. Izdebskiego, S. Stanisławskiego, Warszawa 2010, s. 193. 
z tym związane warunki i sposób wstrzymania tego wykonania ${ }^{6}$. Wskazuje on trzy elementy konstrukcyjne tworzące wykonalność decyzji nieostatecznej: pierwszy - wykonanie decyzji, gdy jest ona zgodna z żądaniem wszystkich stron; drugi: nadanie decyzji rygoru natychmiastowej wykonalności po spełnieniu ustawowych przesłanek; i trzeci, równie ważny element tworzą środki pozwalające na wstrzymanie wykonania decyzji, gdyby jednak okazało się, że przez wykonanie decyzji zostanie naruszony interes społeczny lub interes prawny strony ${ }^{7}$.

Robert Sawuła rozróżnia wykonalność w znaczeniu wąskim i szerokim. W znaczeniu szerokim wykonalność utożsamia z mocą prawną: to wywoływanie wszelkich skutków związanych z obowiązywalnością rozstrzygnięcia, jego funkcjonowaniem w obrocie prawnym. W znaczeniu wąskim to zdatność rozstrzygnięcia do wywołania skutków bezpośrednio określonych w treści samej decyzji. W tym znaczeniu wykonanie decyzji oznacza możliwość spowodowania stanu rzeczywistości zgodnego z treścią rozstrzygnięcia ${ }^{8}$.

$\mathrm{Na}$ brak jednolitości rozumienia wykonalności w doktrynie zwraca uwagę Zbigniew Kmieciak. Podnosi, że w koncepcję wstrzymania wykonania decyzji próbuje „wtłoczyć się” konstrukcję zawieszenia mocy (skutków prawnych) podjętego rozstrzygnięcia. Jego zdaniem wstrzymanie wykonania aktu nie powoduje zawieszenia jego mocy, ale jest związane jedynie z elementem realizacji przyznanych uprawnień bądź wypełnie-

6 M. Święcki, Wykonalność decyzji nieostatecznej według kodeksu postępowania administracyjnego, „Acta Universitatis Nicolai Copernici” 1976, Prawo XIV, Nauki Humanistyczno-Społeczne, z. 75, s. 143.

7 Posłużenie się przez ustawodawcę w art. 135 kpa wyrażeniem, że „organ może w uzasadnionych przypadkach wstrzymać natychmiastowe wykonanie decyzji”, M. Święcki tłumaczy tym, że nie tyle tu chodzi o wstrzymanie wykonania decyzji, rozumiane jako faktyczne zaprzestanie czynności przez stronę, lecz wstrzymanie wykonalności, czyli stwierdzenie niedopuszczalności wykonywania i w związku z tym żądanie faktycznego zaprzestania. Pogląd ten został wypowiedziany w stosunku do art. 118 kpa w pierwotnym brzmieniu, jednak ze względu na przyjęcie takiej samej regulacji w obecnie obowiązującym art. $135 \mathrm{kpa}$, zachowuje on swoją aktualność. Zob. Wykonalność..., s. 154.

8 R. Sawuła, op. cit., s. 193. 
nia nałożonych obowiązków ${ }^{9}$. Wykonanie decyzji administracyjnej odnosi się natomiast do spowodowania przez uprawniony podmiot stanu rzeczywistości zgodnego z treścią rozstrzygnięcia będącego przedmiotem decyzji administracyjnej ${ }^{10}$.

Niekiedy wykonalność aktu administracyjnego, na wzór koncepcji wykonalności $\mathrm{w}$ prawie cywilnym, wiązana jest z możliwością poddania jego egzekucji w przypadku aktów administracyjnych - w drodze postępowania administracyjnego ${ }^{11}$. Takie stanowisko zaledwie fragmentarycznie odnosi się do omawianego zagadnienia, ponieważ obejmuje tylko decyzje nakładające obowiązek, a nie uwzględnia decyzji uprawniających dla strony. Wśród tych ostatnich są również decyzje wykonalne, jednak wszczęcie postępowania egzekucyjnego nie będzie dopuszczalne, ponieważ nie można przymusić strony do wykonania przyznanego jej uprawnienia ${ }^{12}$. Dlatego też bardziej trafne jest stanowisko Henryka Mądrzaka, który twierdzi, że akt administracyjny jest orzeczeniem wykonalnym, jeżeli ze względu na zawartą w nim treść nadaje się do wykonania niezależnie od tego, czy w konkretnym przypadku dopuszczalne jest wszczęcie postępowania egzekucyjnego ${ }^{13}$. Dalej Autor twierdzi, że można odróżnić orzeczenie zdolne do wykonania od innych orzeczeń, których skutek prawny wyczerpuje się w ostatecznym ustaleniu lub ukształtowaniu prawa lub stosunku prawnego ${ }^{14}$.

Wykonalnością aktu administracyjnego zajmuje się również Agnieszka Krawczyk. Wyróżnia ona wykonalność w znaczeniu materialnym i formalnym. Z pierwszym znaczeniem wią-

9 Z. Kmieciak, Ochrona tymczasowa $w$ postępowaniu sądowoadministracyjnym, „Państwo i Prawo” 2003, nr 5, s. 27.

10 Ibidem, s. 27.

11 Postanowienie WSA w Gdańsku sygn. akt II SA/Gd 327/10 z dnia 2 lipca 2010 r. Orzeczenia wykorzystane w artykule, jeżeli nie wskazano inaczej, pochodzą z CBOSA dostępnej na stronie http: \\orzeczenia.nsa.gov.pl.

12 Przegląd koncepcji poszczególnych przedstawicieli doktryny w zakresie wykonalności decyzji uprawniających albo negatywnych przedstawiają K. Defecińska-Tomczak, M. Długońska, E. Frankiewicz, A. Korzeniowska, J. Wyporska, op.cit., s. 81-83.

13 H. Mądrzak, Natychmiastowa wykonalność wyroków $w$ procesie cywilnym $w$ PRL, Wrocław 1965, s. 31.

14 Ibidem, s. 31. 
że, podobnie jak Tadeusz Barnat, tzw. faktyczną wykonalność decyzji, czyli rzeczywistą możliwość zrealizowania uprawnień lub obowiązków zawartych w rozstrzygnięciu decyzji. Źródła takiej wykonalności upatruje w treści art. $156 \S 1$ pkt 5 kpa, stanowiącego podstawę prawną do eliminacji z obrotu przez stwierdzenie nieważności decyzji niewykonalnych faktycznie w dniu ich wykonania, o ile ich niewykonalność ma charakter trwały ${ }^{15}$.

Odnosząc się do wykonalności formalnej, A. Krawczyk wyróżnia w jej ramach cztery postaci wykonania aktu: 1) wykonanie polegające na aktywności zainteresowanego podmiotu - adresata aktu lub organu egzekucyjnego (wykonanie dobrowolne lub przymusowe); 2) wykonanie w szerokim znaczeniu utożsamiane z zaistnieniem mocy obowiązującej aktu; 3) wykonanie jako wystąpienie materialnych skutków następczych aktu; 4) wykonanie jako wyzwolenie wszelkich, materialnych i procesowych skutków aktu (wykonanie jako skuteczność prawna) ${ }^{16}$.

$\mathrm{Z}$ regulacji zawartych w kodeksie postępowania administracyjnego wynika, że decyzji, od której służy odwołanie, może być nadany rygor natychmiastowej wykonalności. Nadanie takiego rygoru zostało uzależnione od spełnienia jednej z następujących przesłanek: gdy jest to niezbędne ze względu na ochronę zdrowia lub życia ludzkiego albo dla zabezpieczenia gospodarstwa narodowego przed ciężkimi stratami bądź też ze względu na inny interes społeczny lub wyjątkowo ważny interes strony. Nie ma przeszkód, aby organ wydając decyzję o środowiskowych uwarunkowaniach, nadał taki rygor decyzjom nieostatecznym, jeżeli wystąpi o to strona i zostaną spełnione warunki określone w art. $108 \mathrm{kpa}^{17}$. Odnosi się to zarówno do

15 A. Krawczyk, Wykonalność aktu i czynności organu administracji publicznej, Warszawa 2013, s. 253 oraz przywołany za Autorką T. Barnat, Ostateczność i prawomocność decyzji administracyjnych a ich wykonalność, PiP 1984, z. 9 , s. 82 .

16 A. Krawczyk, op.cit.,s. 257.

17 Postępowanie takie jest akceptowane przez sądy administracyjne. Taki wniosek można wyciągnąć ze stanowiska sądu administracyjnego wyrażonego w wyroku w sprawie sygn. akt IV SA/Wa 870/11 WSA w Warszawie z dnia 24 października 2011 r., w którym sąd w zakresie rygoru natychmiastowej wykonalności zwrócił jedynie uwagę, że w rozpatrywanej sprawie przesłanki 
decyzji o środowiskowych uwarunkowaniach wydawanych po screeningu, jak i po ocenie, np. gdy decyzja dotyczy oddziaływania na środowisko przedsięwzięcia niezwykle istotnego dla mieszkańców regionu. Z nadaniem rygoru natychmiastowej wykonalności przez organ I instancji wiąże się obowiązek analizy zasadności jego nadania przez organ II instancji w przypadku wniesienia odwołania. Jest to tym bardziej istotne, że nadanie rygoru natychmiastowej wykonalności stanowi wyjątek od zasady niewykonalności decyzji nieostatecznych, stąd przesłanki jego nadania, zawarte w kodeksie, powinny być interpretowane zawężająco.

Jakie skutki wiążą się z nadaniem nieostatecznej decyzji o środowiskowych uwarunkowaniach rygoru natychmiastowej wykonalności? Z pewnością nie powstaje skutek w postaci natychmiastowego obowiązku wykonania decyzji poprzez np. wykonanie nałożonych warunków środowiskowych, jeżeli przeprowadzana była ocena oddziaływania na środowisko. Taki obowiązek będzie się aktualizował po uzyskaniu ostatecznego zezwolenia inwestycyjnego, np. pozwolenia na budowę i to dopiero wraz z rozpoczęciem realizacji inwestycji. Nadanie rygoru natychmiastowej wykonalności decyzji o środowiskowych uwarunkowaniach przynosi inwestorowi wymierną korzyść w postaci możliwości ubiegania się o kolejne zezwolenie wymagane do rozpoczęcia procesu inwestycyjnego (w rozwiązaniach przyjętych $\mathrm{w}$ prawie polskim decyzja o środowiskowych uwarunkowaniach, co do zasady nie jest decyzją inwestycyjną development consent w rozumieniu dyrektywy Parlamentu Europejskiego i Rady 2011/92/UE z dnia 13 grudnia 2011 r. w sprawie oceny skutków wywieranych przez niektóre przedsięwzięcia publiczne i prywatne na środowisko. Tekst mający znaczenie dla EOG; dalej: dyrektywa 2011/92 ${ }^{18}$ ). Uważa się, że decyzja wów-

jego nadania nie zostały w sposób wystarczający uzasadnione, nie kwestionując dopuszczalności nadania rygoru. W innej sprawie WSA zarzucił, że SKO uchylając rygor natychmiastowej wykonalności nadany przez organ I instancji, nie w pełni uzasadniło zajęte stanowisko, zob. wyrok WSA w Kielcach z dnia 29 czerwca 2011 r., sygn. akt II SA/Ke 292/11.

18 Dz.Urz. UE L 335 z 17.12.2011, s. 1. 
czas wywołuje m.in. taki skutek, że może zostać załączona do wniosku o wydanie kolejnej decyzji administracyjnej. Wskazuje to na rozumienie wykonalności decyzji o środowiskowych uwarunkowaniach sensu largo, utożsamiane z zaistnieniem mocy obowiązującej aktu.

Innym momentem, w którym istotna jest cecha wykonalności aktu jest udzielanie ochrony tymczasowej w związku z wniesieniem skargi do sądu administracyjnego. Artykuł 61 ustawy z dnia 30 sierpnia 2002 r. Prawo o postępowaniu przed sądami administracyjnymi ${ }^{19}$ stanowi wprost, że wniesienie skargi do sądu nie wstrzymuje wykonania aktu lub czynności (§ 1). Organ, który wydał skarżone orzeczenie, działając z urzędu lub na wniosek, oraz sąd działając na wniosek, może wstrzymać wykonanie postanowienia lub decyzji. W przypadku sądu wstrzymanie wykonania uzależnione jest od spełnienia przynajmniej jednej z dwóch następujących przesłanek: istnieje niebezpieczeństwo wyrządzenia znacznej szkody lub spowodowania trudnych do odwrócenia skutków (art. 61 § 3 p.p.s.a.).

W doktrynie powszechne jest stanowisko, że zapewnienie przez sąd ochrony tymczasowej dotyczy sytuacji, w której akt organu nadaje się do wykonania (ma przymiot wykonalności) ${ }^{20}$ i nie został jeszcze w pełni wykonany ${ }^{21}$. Przez pojęcie wykonania aktu administracyjnego rozumie się spowodowanie w sposób dobrowolny lub przymusowy zaistnienia takiego stanu rzeczy, który jest zgodny z rozstrzygnięciem zawartym w danym akcie. Wykonalność dotyczy zatem aktów zobowiązujących, które ustalają dla ich adresatów nakazy powinnego zachowania lub zakazy określonego zachowania, aktów, na podstawie

19 Dz.U. 2012 r., poz. 270, ze zm., dalej: p.p.s.a.

20 M. Romańska [w:] Postępowanie sq̨dowo administracyjne, pod red. T. Wosia, Warszawa 2011, s. 192; Prawo o postępowaniu przed sądami administracyjnymi. Komentarz, pod red. R. Hausera, M. Wierzbowskiego. Warszawa 2013, wyd. 2, komentarz do art. 61, s. 359 i nast.; J. P. Tarno, Prawo o postępowaniu przed sądami administracyjnymi. Komentarz, Warszawa 2006, s. 186.

21 Skoro postanowienie o wstrzymaniu wykonania zaskarżonej decyzji ma uchronić stronę przed skutkami wykonania zaskarżonego aktu, to fakt wykonania niweczy cel zastosowania instytucji (np. postanowienie NSA z dnia 19 czerwca 2008 r., II OZ 621/08). 
których określony podmiot uzyskuje równocześnie uprawnienie i mocą którego zostają na niego nałożone określone obowiązki, oraz aktów, na podstawie których jeden podmiot jest do czegoś zobowiązany, a drugi wyłącznie uprawniony ${ }^{22}$. Wskazuje to na najwęższe rozumienie wykonalności. Sądy odmawiały wstrzymania wykonania, np. decyzji odmawiającej stwierdzenia nieważności decyzji ${ }^{23}$.

Z orzecznictwa sądów administracyjnych wynika, że nie jest możliwe wstrzymanie wykonania decyzji o środowiskowych uwarunkowaniach. Towarzyszy temu założenie, że decyzje takie nie mają cechy wykonalności i przez to nie mogą wyrządzić znacznej szkody ${ }^{24}$. Innym powodem odmowy udzielania ochrony tymczasowej wskazywanym w orzecznictwie jest niemożność spełnienia ustawowych przesłanek uchylenia takiego rygoru, już bez odnoszenia się do cechy wykonalności ${ }^{25}$.

Brak przyznania ochrony tymczasowej w orzecznictwie argumentuje się również w ten sposób, że decyzja o środowiskowych uwarunkowaniach stanowi etap procesu inwestycyjnego, który daje inwestorowi prawo do wystąpienia o pozwolenie na budowę, czy o inną decyzję inwestycyjną, jak np. koncesja, i nie stanowi aktu dającego podstawę do rozpoczęcia robót i realizacji inwestycji, nie narusza więc na tym etapie żadnych praw przez wyrządzenie znacznej szkody lub spowodowanie nieodwracalnych skutków. Do wykonania, uzasadniają dalej sądy, nadawałaby się decyzja o pozwoleniu na realizację inwestycji. Ponadto wskazują, że decyzja o środowiskowych uwarunkowaniach nie podlega wykonaniu w drodze postępowania egzeku-

22 T. Woś [w:] tenże (red.), H. Knysiak-Molczyk, M. Romańska, Prawo o postępowaniu przed sądami administracyjnymi. Komentarz, Warszawa 2006, s. 295 i nast.

23 Postanowienie NSA z dnia19 lutego 2009 r., sygn. akt II FSK 136/09.

24 Tak np. przywoływane już postanowienie sygn. akt II SA/Gd 327/10, jak również postanowienie NSA z dnia 7 sierpnia 2011 r., sygn. akt II OZ 564/11, postanowienie NSA z dnia 7 kwietnia 2011 r., sygn. akt II OZ 271/11, postanowienie NSA z dnia 6 lipca 2010 r., sygn. akt II OZ 658/10, postanowienie NSA z dnia 24 maja 2012 r., sygn. akt II OSK 1160/12.

25 Por. postanowienie WSA w Krakowie z dnia 26 października 2011 r. sygn. akt II SA/Kr 395/11. 
cyjnego, a jej istnienie nie naraża skarżących na żadne szkody. Ewentualne szkody bądź trudne do odwrócenia skutki mogą nastąpić dopiero z wydaniem w przyszłości, np. decyzji o pozwoleniu na budowę, która będzie stanowiła podstawę realizacji przedsięwzięcia ${ }^{26}$.

Przywołane orzecznictwo dotyczące decyzji o środowiskowych uwarunkowaniach pozwala na sformułowanie oceny, że wykonalność decyzji, o której mowa w art. $61 \S 3$ p.p.s.a., jest traktowana w sposób wąski.

Trudności odnoszące się do jednoznacznej kwalifikacji decyzji o środowiskowych uwarunkowaniach wynikają z jej złożonego charakteru. Rozstrzygnięcie zawierane w decyzji zależy od tego, czy była przeprowadzana ocena oddziaływania na środowisko, czy nie. W drugim przypadku, w decyzji o środowiskowych uwarunkowaniach właściwy organ stwierdza brak potrzeby przeprowadzenia oceny (patrz: art. 84 ustawy ocenowej). Natomiast w pierwszym - rozstrzygnięcie jest bardziej rozbudowane i obejmuje m.in. rodzaj i lokalizację przedsięwzięcia, warunki wykorzystywania terenu $\mathrm{w}$ fazie realizacji i eksploatacji lub użytkowania przedsięwzięcia, ze szczególnym uwzględnieniem konieczności ochrony cennych wartości przyrodniczych, zasobów naturalnych i zabytków oraz ograniczenia uciążliwości dla terenów sąsiednich. Ponadto, jeżeli z oceny oddziaływania tak wynika, organ nakłada obowiązek wykonania kompensacji przyrodniczej oraz obowiązek zapobiegania, ograniczania oraz monitorowania oddziaływania przedsięwzięcia na środowisko (patrz: art. 82 ustawy ocenowej). Kilka słów wyjaśnienia warto poświęcić również warunkom wykorzystywania terenu. Przyjmując jako kryterium czas ich realizacji, można wyróżnić te od-

26 Zob. np. przywoływane postanowienie sygn. akt II SA/Gd 327/10, jak również postanowienie NSA z dnia 27 stycznia 2011 r., sygn. akt II OZ 28/11, postanowienie NSA z dnia 7 kwietnia 2011 r., sygn. akt II OZ 271/11, postanowienie NSA z dnia 8 lipca 2011 r., sygn. akt II OZ 564/11, postanowienie WSA w Poznaniu z dnia 18 stycznia 2011 r. sygn. akt IV SA/Po 1027/10, postanowienie NSA z dnia 1 lutego 2010 r., sygn. akt II OZ 35/10; postanowienie WSA w Łodzi z dnia 22 października 2010 r., sygn. akt II SA/Łd 1042/10, postanowienie WSA w Poznaniu z dnia 15 grudnia 2011 r., sygn. akt II SA/Po $736 / 11$. 
noszące się do etapu realizacji inwestycji i te wskazujące, w jaki sposób powinien zostać przygotowany, np. projekt budowlany. Wykonywanie tych ostatnich rozpoczyna się, jeszcze zanim dojdzie do rozpoczęcia etapu inwestycyjnego. Natomiast wykonywanie warunków wykorzystania terenu odnoszących się do etapu realizacji inwestycji ulega niejako „zawieszeniu” do czasu uzyskania ostatecznego pozwolenia uprawniającego do rozpoczęcia robót, np. pozwolenia budowlanego. Analizując jeszcze bardziej szczegółowo zagadnienie można zauważyć, że w decyzji mogą zostać zawarte rodzaje warunków: odnoszące się do etapu wykonywania czy funkcjonowania. Zatem to przejście do określonego etapu realizacji będzie aktywowało obowiązek wykonywania danego rodzaju warunków.

Postępowanie administracyjne prowadzone przed wydaniem decyzji nie ogranicza się tylko do analizy zebranego materiału dowodowego w sprawie i ustosunkowania się do inwestycji w kształcie zaproponowanym przez inwestora, ale ustawodawca przyznał organowi prawo do wskazania innego wariantu, jeżeli z oceny oddziaływania przedsięwzięcia na środowisko wynika zasadność realizacji przedsięwzięcia w wariancie innym niż proponowany przez wnioskodawcę. Zaproponowanie nowego wariantu wymaga zgody inwestora, a w przypadku jej braku stanowi podstawę do wydania decyzji negatywnej (patrz art. 81 ustawy ocenowej).

Przywołana argumentacja odwołująca się do braku możliwości wykonania decyzji o środowiskowych uwarunkowaniach w drodze postępowania egzekucyjnego pomija fakt, że decyzja o środowiskowych uwarunkowaniach wydana po ocenie oddziaływania przedsięwzięcia na środowisko takiej egzekucji podlega ${ }^{27} \mathrm{w}$ zakresie m.in. zawartych $\mathrm{w}$ niej warunków wykorzystania terenu, jak również innych elementów nakazujących

27 Mało precyzyjnemu sformułowaniu zawartym w decyzji o środowiskowych uwarunkowaniach sąd administracyjny zarzucił, że „[s]posób [...] sformułowania wymagania jest na tyle ogólnikowy, że decyzja w tym zakresie nie jest możliwa do egzekwowania, ponieważ z jej treści nie wynika dla zobowiązanego, w jaki sposób ma uczynić zadość nałożonym obowiązkom”. Zob. przywołany już wyrok w sprawie o sygn. akt IV SA/Wa 870/11. 
w określony sposób realizację inwestycji. Stanowią one dla inwestora wiążące rozstrzygnięcie, w jaki sposób, ze względów środowiskowych, powinien realizować inwestycję i w toku tej realizacji muszą zostać wykonywane. W tym zakresie można decyzję o środowiskowych uwarunkowaniach zakwalifikować jako akt zawierający i uprawnienia, i obowiązki ${ }^{28}$. Natomiast pozytywna decyzja o środowiskowych uwarunkowaniach wydawana w postępowaniu bez oceny oddziaływania na środowisko, czyli ta niezawierająca warunków (moim zdaniem w tej decyzji nie jest dopuszczalne określanie warunków wykorzystania terenu), stanowi uprawnienie do kontynuowania procesu inwestycyjnego i w tym zakresie, jak już zauważono, egzekwowanie jej nie jest możliwe.

Relacja pomiędzy decyzją o środowiskowych uwarunkowaniach (wydaną po ocenie oddziaływania na środowisko) a kolejną decyzją inwestycyjną nie wyczerpuje się jedynie w konieczności posiadania pierwszej jako warunku rozpoczęcia kolejnego postępowania administracyjnego w celu otrzymania drugiej. Przystępując do realizacji inwestycji, inwestor jest zobowiązany do przestrzegania nie tylko warunków wynikających z decyzji inwestycyjnej, ale również z innych decyzji, w tym decyzji o środowiskowych uwarunkowaniach. Wydanie kolejnej decyzji administracyjnej w postępowaniu mającym na celu zdobycie niezbędnych pozwoleń do rozpoczęcia inwestycji w żadnym wypadku nie zwalnia inwestora z obowiązku przestrzegania warunków środowiskowych nałożonych w decyzji o środowiskowych uwarunkowaniach. Na koniec warto zauważyć, że załącznikiem do obu decyzji jest charakterystyka przedsięwzięcia, opisująca przedsięwzięcie. Jest ona szczególnie istotna w przypadku decyzji wydawanej bez oceny, ponieważ pozwala organowi prowadzącemu kolejne postępowanie admi-

28 Przywołane cechy decyzji o środowiskowych uwarunkowaniach w pełni wpisują się w charakterystykę decyzji wykonalnej przedstawioną przez M. Romańską: „[...] problem wykonania aktu administracyjnego dotyczy aktów zobowiązujących, ustalających dla ich adresatów nakazy powinnego zachowania lub zakazy określonego zachowania, aktów, na podstawie których określony podmiot uzyskuje równocześnie uprawnienie i mocą którego zostają na niego nałożone określone obowiązki [...]", op. cit., s. 192. 
nistracyjne w procesie inwestycyjnym na stwierdzenie tożsamości przedsięwzięcia.

Na stanowisko odnoszące się do braku bezpośredniej wykonalności decyzji, związane z czasowym „zawieszeniem” wykonania warunków wykorzystania terenu zawartych w decyzji o środowiskowych uwarunkowaniach do wydania ostatecznej decyzji inwestycyjnej, konieczne jest spojrzenie z perspektywy upływu czasu. Może zdarzyć się, że czas niezbędny do wydania orzeczenia sądowego w sprawie, w której kontrolowana jest decyzja o środowiskowych uwarunkowaniach będzie znacznie dłuższy niż czas niezbędny do wydania decyzji inwestycyjnej (np. w przypadku pozwolenia budowlanego, ustawa $\mathrm{z}$ dnia 7 lipca 1994 r. Prawo budowlane ${ }^{29}$ w art. 35 ust. 6 przewiduje sankcję finansową $\mathrm{w}$ przypadku niewydania decyzji $\mathrm{w}$ terminie 65 od dnia wszczęcia postępowania). Jako przykład przytoczę daty najważniejszych rozstrzygnięć w jednej ze spraw: w sierpniu 2007 r. została wydana decyzja o środowiskowych uwarunkowaniach przez organ I instancji, w marcu 2008 r. została wydana decyzja organu II instancji utrzymująca w mocy decyzję organu I instancji. Po wniesieniu skarg, postępowanie przed sądem administracyjnym zakończyło się rozstrzygnięciem NSA w lipcu 2012 r. WSA uchylił wydane w 2007 r. i 2008 r. decyzje o środowiskowych uwarunkowaniach, a NSA oddalił wniesioną skargę kasacyjną (wyrok NSA w sprawie sygn. akt II OSK 708/11). Przywołane daty wydania decyzji przez SKO i orzeczenia NSA kończącego postępowanie są odległe, ale nie chodzi tu o podkreślanie długości postępowań prowadzonych przez sądy administracyjne, bo te z natury rzeczy muszą trwać, ale na konsekwencje takiego stanu z jednej strony dla inwestora i z drugiej - dla ochrony środowiska.

Posiadanie ostatecznej decyzji o środowiskowych uwarunkowaniach (której wykonalności nie wstrzymano) pozwala na wszczęcie postępowania i uzyskania ostatecznego zezwolenia pozwalającego na rozpoczęcie inwestycji. Nawet w przypadku zaskarżenia decyzji środowiskowej do sądu administracyjnego czas niezbędny do zakończenia postępowania przed sądem

29 T.j. Dz.U. z 2010 r. Nr 243, poz. 1623, ze zm. 
może okazać się wystarczający do zrealizowania inwestycji. Wstrzymywanie wykonania decyzji na podstawie art. 61 p.p.s.a. zapobiegłoby takim sytuacjom.

Realizacja inwestycji zanim decyzja o środowiskowych uwarunkowaniach stanie się prawomocna, przez co rozumiem zakończenie przez sąd administracyjny kontroli rozstrzygnięcia organu administracyjnego, może podważyć cel, w jakim decyzja ta jest wydawana. Jest nim - przypomnę - ocena wpływu planowanego przedsięwzięcia na środowisko. Podkreślenia wymaga, że nie chodzi tu o ocenę jakiegokolwiek przedsięwzięcia. Musi być ono na etapie planowania (moim zdaniem), ponieważ tylko wtedy jest możliwe dostosowanie planów inwestycyjnych ze względów środowiskowych. Przeprowadzenie oceny oddziaływania na środowisko na jak najwcześniejszym etapie postępowania inwestycyjnego, gdy jeszcze wszystkie rozwiązania są dostępne wynika z pkt 2 dyrektywy 2011/92. W przypadku decyzji wydanej po ocenie oddziaływania na środowisko, niewłaściwie określone warunki wynikające $\mathrm{z}$ np. nieprawidłowego ustalenia istnienia gatunków chronionych występujących w zasięgu oddziaływania na środowisko, czy też braku ustalenia oddziaływania przedsięwzięcia na gatunki chronione, w wypadku realizacji inwestycji wywołają często nieodwracalne szkody w środowisku.

Daleko idąca w skutkach środowiskowych (negatywnych) jest realizacja inwestycji opartej na decyzji środowiskowej wydanej bez oceny, gdy sąd administracyjny po kontroli takiej decyzji stwierdzi, że organ administracyjny nie ustalił w sposób prawidłowy podstaw do odstąpienia od przeprowadzenia oceny.

W ochronie środowiska najbardziej doniosłe znaczenie mają instrumenty o charakterze prewencyjnym, zapobiegające zniszczeniu środowiska, a podstawowymi zasadami są zasady przezorności i zapobiegania. Do instrumentów prewencyjnych należy również decyzja o środowiskowych uwarunkowaniach.

Orzeczenie przez sąd o uchyleniu decyzji o środowiskowych uwarunkowaniach i nakazaniu rzetelnego przeprowadzenia postępowania mającego zbadać stopień zagrożenia przedsięwzięcia na środowisko nawet po ok. 4 latach od dnia, w którym decyzja stała się ostateczna, byłoby bardziej zasad- 
ne, gdyby nie doszło do zrealizowania inwestycji, jak w sprawie podanej jako przykład w poprzednim akapicie. Powyższe argumenty wskazują, że badanie pod kątem spowodowania trudnych do odwrócenia skutków w przypadku spraw z ochrony środowiska wymaga ostrożnego podejścia. Trudne jest do zaakceptowania stanowisko wykluczające możliwość spełnienia jednej z przesłanek z art. $61 \S 3$ p.p.s.a. ze względu na charakter decyzji środowiskowej.

Odmawianie udzielenia ochrony tymczasowej oparte na uzasadnieniu, że decyzja o środowiskowych uwarunkowaniach nie naraża na wystąpienie szkody, która może powstać dopiero po wydaniu np. pozwolenia na inwestycję, można skonfrontować z następującymi argumentami. Zwrócenia uwagi wymaga fakt, że w obu postępowaniach (dotyczącym wydania decyzji o środowiskowych uwarunkowaniach i odnoszącym się do wydania decyzji inwestycyjnej) ochronie podlegają różne interesy prawne, stanowiące m.in. kryterium wyznaczające strony postępowania. Inaczej też kształtują się uprawnienia podmiotów na prawach strony. Oznacza to, że w postępowaniu w przedmiocie środowiskowych uwarunkowań krąg stron (podmiotów na prawach strony) nie musi być taki sam jak w postępowaniu $\mathrm{w}$ przedmiocie wydania, np. pozwolenia na budowę. W konsekwencji strona, której interes prawny podlega ochronie na etapie postępowania środowiskowego, a nie na etapie pozwolenia na budowę, nie będzie stroną tego drugiego postępowania, nie będzie zatem mogła skorzystać ze środków zaskarżenia rozstrzygnięć w nim zapadłych, w tym wnosić żądania wstrzymania wykonania takiego pozwolenia. Takie ograniczenie dotyczy również Generalnego Dyrektora Ochrony Środowiska, utworzonego do realizacji zadań z zakresu ochrony środowiska. Ustawa ocenowa przyznaje prawo do uczestniczenia temu organowi jako podmiot na prawach strony tylko w postępowaniach dotyczących wydawania decyzji o środowiskowych uwarunkowaniach (patrz art. 76), a nie w postępowaniach, których przedmiotem jest wydanie jednej z decyzji wymienionych $\mathrm{w}$ art. 72 ustawy ocenowej.

Przywołany argument wiążący rzeczywiste powstanie szkody z decyzją umożliwiającą rozpoczęcie prac inwestycyj- 
nych (nazwę ją decyzją inwestycyjną, np. pozwolenie na budowę) zawiera pewną nieścisłość polegającą na pomijaniu tego, że źródło szkody będzie znajdowało się w decyzji o środowiskowych uwarunkowaniach, a nie w tej drugiej decyzji. Powstaje w związku z tym zapytanie o dopuszczalność interpretacji art. 61 p.p.s.a. polegającej na wstrzymaniu wykonania decyzji inwestycyjnej, nie ze względu na rozstrzygnięcia zawarte $w$ tej decyzji, ale na rozwiązania zawarte w innej decyzji, w tym wypadku w decyzji o środowiskowych uwarunkowaniach.

Kolejny argument przemawiający za przyznawaniem ochrony tymczasowej odwołuje się do obowiązków przyjętych przez Polskę wraz z ratyfikacją Konwencji sporządzonej w Aarhus dnia 25 czerwca 1998 r. o dostępie do informacji, udziale społeczeństwa $\mathrm{w}$ podejmowaniu decyzji oraz dostępie do sprawiedliwości w sprawach dotyczących środowiska, zwaną dalej Konwencją z Aarhus ${ }^{30}$, jedną z podstawowych konwencji w ochronie środowiska. Zobowiązuje ona każdą ze stron do tego, że w sprawach dotyczących środowiska zapewni ona prawo dostępu do informacji, udziału społeczeństwa w podejmowaniu decyzji oraz dostępu do wymiaru sprawiedliwości zgodnie z postanowieniami tej konwencji ${ }^{31}$. Moim zdaniem decyzja o środowiskowych uwarunkowaniach wydawana po przeprowadzeniu oceny oddziaływania na środowisko niewątpliwie mieści się w tym zakresie. Wśród aspektów dostępu do wymiaru sprawiedliwości, w art. 9 ust. 4 Konwencja z Aarhus zobowiązuje stronę konwencji do stworzenia procedur, które „przewidywać będą odpowiednie i prawnie skuteczne środki zaradcze, włączając $\mathrm{w}$ to, jeśli okaże się to potrzebne, wstrzymanie wykonania kwestionowanego działania, oraz będą bezstronne, oparte na

30 W ustawie z dnia 21 czerwca 2001 r. o ratyfikacji Konwencji o dostępie do informacji, udziale społeczeństwa w podejmowaniu decyzji oraz dostępie do sprawiedliwości w sprawach dotyczących środowiska (Dz.U. Nr 89, poz. 970) Parlament wyraził zgodę na ratyfikację Konwencji z Aarhus. Następnie dokument ratyfikacyjny został podpisany przez Prezydenta RP dnia 31 grudnia 2001 r. W dniu 15 lutego 2002 r. dokument ten złożono u Depozytariusza Konwencji (Sekretarza Generalnego ONZ w Nowym Jorku). Konwencja została opublikowana 9 maja 2003 r. (Dz.U. Nr 78, poz. 706).

31 Zob. art. 1 Konwencji z Aarhus. 
zasadzie równości, terminowe i niedyskryminacyjne ze względu na koszty".

Stanowisko reprezentujące wykonalność decyzji w ujęciu szerokim zajął WSA w Gdańsku w wyroku z dnia 30 listopada 2010 r. o sygn. akt II SA/Gd 754/10. Odnosząc się do realizacji $\mathrm{w}$ prawie polskim wymagania zawartego w art. 9 ust. 4 Konwencji z Aarhus wskazał, że to właśnie art. $61 \S 2$ i 3 p.p.s.a. spełnia tę funkcję. „W sytuacji wniesienia do sądu skargi na taką decyzję [decyzję o środowiskowych uwarunkowaniach zgody na realizację przedsięwzięcia ${ }^{32}$ ], organ, a następnie sąd na wniosek skarżącego, może bowiem wstrzymać wykonanie zaskarżonej decyzji. Wstrzymanie wykonania decyzji niweczy czasowo jej skutki i powoduje, iż do czasu rozpatrzenia skargi nie może ona stanowić podstawy wydania decyzji zezwalającej na realizację inwestycji drogowej". Sprawa, w której wypowiadał się sąd, nie dotyczyła jednak decyzji o środowiskowych uwarunkowaniach, ale właśnie decyzji o zezwoleniu na realizację inwestycji drogowej.

Odwołując się do przywołanych na początku artykułu wypowiedzi doktryny, dotyczących rozumienia cechy wykonalności, należy stwierdzić, że decyzja o środowiskowych uwarunkowaniach zawierająca warunki wykorzystania terenu jest zdolna do wykonania w ujęciu koncepcji wąskiego jak również szerokiego rozumienia wykonalności. Co więcej, możliwe będzie wykorzystanie postępowania egzekucyjnego w celu wykonania rozstrzygnięcia zawartego $\mathrm{w}$ tej decyzji, z zastrzeżeniem opisanym powyżej, że możliwość ta aktualizuje się na odpowiednim etapie procesu inwestycyjnego, o ile inwestor przeprowadza go z naruszeniem warunków środowiskowych. Okoliczność, że wykonywanie części warunków jest „zawieszone” do czasu rozpoczęcia procesu inwestycyjnego, nie powinna stanowić uza-

32 Chociaż orzeczenie zapadło pod rządami wcześniej obowiązującego stanu prawnego, tj. gdy zagadnienia związane $\mathrm{z}$ oceną oddziaływania na środowisko zawarte były w ustawie z dnia 27 kwietnia 2001 r. Prawo ochrony środowiska, a decyzja regulująca zagadnienia środowiskowe przy realizacji przedsięwzięć nazywała się decyzją o środowiskowych uwarunkowaniach zgody na realizację przedsięwzięcia, stanowisko zachowuje aktualność także w obecnym stanie prawnym. 
sadnienia dla odmowy udzielania ochrony tymczasowej z wcześniej wskazanych przyczyn.

Powołanie się na argument łączący wykonalność decyzji ze zdolnością do poddania jej egzekucji zawodzi w przypadku pozytywnej decyzji o środowiskowych uwarunkowaniach wydanej po przeprowadzeniu postępowania screeningowego, bez oceny oddziaływania na środowisko. Nie ulega wątpliwości, że wszczęcie postępowania egzekucyjnego nie będzie możliwe w stosunku do takiej decyzji. Konieczne jest jednak zwrócenie uwagi na inny aspekt: rozstrzygnięcie o braku konieczności przeprowadzenia oceny oddziaływania na środowisko uprawnia do kontynuowania procesu inwestycyjnego. Strona-inwestor kierując wniosek o wszczęcie kolejnego postępowania administracyjnego, np. w przedmiocie pozwolenia budowlanego, będzie czerpała korzyści z posiadanej pozytywnej decyzji o środowiskowych uwarunkowaniach. Przypisanie działaniu polegającemu na wykorzystaniu decyzji o środowiskowych uwarunkowaniach jako załącznik do wniosku o wszczęcie kolejnego postępowania będzie mieściło się w koncepcji wykonalności decyzji w znaczeniu szerokim, wiążącej wykonalność z wywoływaniem wszelkich skutków związanych z obowiązywalnością rozstrzygnięcia. Jednym z takich skutków jest wymieniona możliwość kontynuowania procesu inwestycyjnego.

Z żądaniem przyznania ochrony tymczasowej wniesionym wraz ze skargą do sądu administracyjnego, po stronie organu, ewentualnie sądu, skorelowany jest obowiązek analizy ustawowych przesłanek pozwalających na udzielenie tej ochrony. Odwołując się do koncepcji wykonalności decyzji w znaczeniu szerokim, wstrzymanie wykonania decyzji o środowiskowych uwarunkowaniach spowoduje, że strona-inwestor nie będzie mogła kontynuować postępowania inwestycyjnego do czasu wydania orzeczenia przez sąd, a w przypadku uchylenia zaskarżonej decyzji, do czasu wydania ostatecznej decyzji o środowiskowych uwarunkowaniach. W konsekwencji rozstrzygnięcie zawarte w zaskarżonej decyzji o środowiskowych uwarunkowaniach nie będzie mogło być brane pod uwagę podczas kolejnego rozstrzygnięcia administracyjnego. 
Mając na uwadze powyższe argumenty, wydaje się, że nie ma przeszkód, aby wyrażenie „wykonanie” decyzji, o którym mowa w art. $61 \S 3$ p.p.s.a., było interpretowane w stosunku do decyzji o środowiskowych uwarunkowaniach w taki sam sposób jak art. 152 p.p.s.a., w myśl którego w razie uwzględnienia skargi sąd w wyroku określa, czy i w jakim zakresie zaskarżony akt lub czynność nie mogą być wykonane. „W przypadku stosowania art. 152 ustawy z dnia 30 sierpnia 2002 r. - Prawo o postępowaniu przed sądami administracyjnymi [...] $\mathrm{w}$ razie uwzględnienia skargi na decyzję chodzi o wykonalność decyzji w szerokim znaczeniu, podobnie jak szerokie znaczenie ma »wykonanie decyzji« w rozumieniu art. 130 § 1 i 2 Kodeksu postępowania administracyjnego." ${ }^{33} \mathrm{~W}$ wyrokach kończących kontrolę wydania decyzji o środowiskowych uwarunkowaniach sądy rozstrzygają o kwestii wykonania tej decyzji ${ }^{34}$. Proponowana wykładnia pozostaje zgodna z konstytucją, w szczególności z art. 74 ust. 2 nakładającym obowiązek na władze publiczne, do których też należą sądy, ochrony środowiska, jak również z zasadami ochrony środowiska - zasadą prewencji i przezorności.

Taka interpretacja pozwoli na udzielanie ochrony prawnej przy wnoszeniu skargi do sądu administracyjnego. Wydaje się, że pozostanie też zgodna z oczekiwaniami ustawodawcy, który zawierając w art. $61 \S 3$ p.p.s.a., wskazał alternatywnie dwie przesłanki, od spełnienia których sąd powinien orzec o wstrzymaniu wykonania aktu: zachodzi niebezpieczeństwo wyrządzenia znacznej szkody lub spowodowania trudnych do odwrócenia skutków. Konkretyzacja spełnienia się jednego z warunków wymaga badania ad casum każdej sprawy. Skutki, jakie zawierająca błędy decyzja o środowiskowych uwarunkowaniach może wywołać w środowisku, są nie tylko trudne do odwrócenia, ale wręcz w pewnych sytuacjach niemożliwe do odwrócenia. Pa-

33 Wyrok NSA z dnia 29 lipca 2004 r., sygn. akt OSK 591/04.

34 Np. wyrok WSA w Krakowie z dnia 27 lutego 2013 r., sygn. akt II SA/Kr 1722/12; wyrok WSA w Lublinie z dnia 31 stycznia 2013 r., II SA/Lu 1043/12; wyrok WSA w Łodzi z dnia 29 stycznia 2013 r., sygn. akt II SA/Łd 901/12; wyrok WSA w Krakowie z dnia 27 listopada 2012 r., sygn. akt II SA/Kr 1349/12. 
trzenie na proces inwestycyjny jako na całość i wskazywanie, że udzielenie ochrony tymczasowej powinno dotyczyć tylko decyzji umożliwiającej rozpoczęcie realizacji inwestycji jest trudne do zaakcpetowania, jeżeli się weźmie pod uwagę fakt, że w prawie polskim proces ten składa się z kilku rozstrzygnięć administracyjnych noszących cechy podwójnej konkretności (każdy $\mathrm{z}$ nich).

\section{BIBLIOGRAFIA}

Barnat T., Ostateczność i prawomocność decyzji administracyjnych a ich wykonalność, „Państwo i Prawo” 1984, z. 9.

Borkowski J., System prawa administracyjnego, T. 9, Prawo procesowe administracyjne, pod red. B. Adamiak, J. Borkowskiego, A. Skoczylasa, Warszawa 2010.

Defecińska-Tomczak K., Długońska M., Frankiewicz E., Korzeniowska A., Wyporska J., Wybrane zagadnienia z zakresu wykonalności decyzji administracyjnej, [w:] Procedura administracyjna wobec wyzwań wspótczesności, Łódź 2004.

Dobrowolski G., Decyzja o środowiskowych uwarunkowaniach, Toruń 2011.

Kmieciak Z., Ochrona tymczasowa $w$ postępowaniu sq̨dowoadministracyjnym, PiP 2003, nr 5.

Krawczyk A., Wykonalność aktu i czynności organu administracji publicznej, Warszawa 2013.

Hauser R., Wierzbowski M. (red.), Prawo o postępowaniu przed sądami administracyjnymi. Komentarz, Warszawa 2013.

Mądrzak H., Natychmiastowa wykonalność wyroków $w$ procesie cywilnym $w$ PRL, Wrocław 1965.

Pchałek M., Behnke M., Postępowanie w sprawie oceny oddziaływania na środowisko $w$ prawie polskim i UE, Warszawa 2009.

Postępowanie sq̨dowoadministracyjne, pod red. T. Wosia, Warszawa 2011.

Sawuła R., Materialnoprawne aspekty wstrzymania wykonania decyzji administracyjnej, [w:] Wspótzależność dyscyplin badawczych w sferze administracji publicznej, pod red. S. Wrzoska, M. Domagały, J. Izdebskiego, S. Stanisławskiego, Warszawa 2010.

Święcki M., Wykonalność decyzji nieostatecznej wedtug kodeksu postępowania administracyjnego, „Acta Universitatis Nicolai Copernici 1976", Prawo XIV, Nauki Humanistyczno-Społeczne, z. 75. 
Tarno J. P., Prawo o postępowaniu przed sądami administracyjnymi. Komentarz, Warszawa 2006.

Woś T. (red.), H. Knysiak-Molczyk, M. Romańska, Prawo o postępowaniu przed sądami administracyjnymi. Komentarz, Warszawa 2006.

Kontakt e-mail:

akosieradzka@wp.pl 